\title{
Pendampingan Guru-Guru Sekolah Dasar Mendesain Pembelajaran Tematik Berbasis Alat Peraga Di Kecamatan Medan Helvetia
}

\author{
Muhammad Aswin Rangkuti ${ }^{1}$, Imelda Free Unita Manurung ${ }^{2}$, Nelson Tarigan ${ }^{3}$, Deo Demonta \\ Panggabean $^{4 *}$, Irfandi ${ }^{5}$, Mukti Hamjah Harahap ${ }^{6}$, Dedy Husrizal Syah ${ }^{7}$ \\ 1,4,5,6 Jurusan Fisika, Fakultas Matematika dan Ilmu Pengetahuan Alam, Universitas Negeri Medan \\ ${ }^{2}$ Jurusan PGSD, Fakultas Ilmu Pendidikan, Universitas Negeri Medan \\ ${ }^{3}$ Jurusan Seni Rupa, Fakultas Bahasa dan Seni, Universitas Negeri Medan \\ ${ }^{7}$ Jurusan Akuntansi, Fakultas Ekonomi, Universitas Negeri Medan \\ 1 aswin.rangkuti.89@gmail.com \\ 2imeldafum@gmail.com \\ ${ }^{3}$ nelsontarigan196104@gmail.com \\ ${ }^{4}$ deo.panggabean@unimed.ac.id \\ 5irfandi@unimed.ac.id \\ ${ }^{6}$ mhfis08@gmail.com \\ 7 dedy@unimed.ac.id
}

\begin{abstract}
ABSTRAK
Mitra pada kegiatan PKM ini adalah SD Swasta Teladan Sumatera Utara. Permasalahan yang dialami oleh mitra yaitu : 1) Minimnya pengetahuan guru-guru tentang pembelajaran yang inovatif sehingga pembelajaran berlangsung secara konvensional dan monoton, 2) Sebagian guru belum mendapatkan pelatihan kurikulum 2013 sehingga kesulitan dalam menerapkannya, 3) Sebagian guru tidak mampu merancang Rencana Pelaksanaan Pembelajaran (RPP) dengan baik, 4) Tidak tersedianya alat peraga pembelajaran, 5) Minimnya keterampilan guru-guru dalam pembuatan alat peraga edukatif tematik. Metode pendekatan dalam pelaksanaan PKM ini menggunakan metode pendidikan, pelatihan, praktik dan pendampingan. Luaran yang dihasilkan antara lain: 1) Meningkatnya pengetahuan guru tentang pembelajaran inovatif di sekolah dasar, 2) Meningkatnya pengetahuan guru-guru dalam menerapkan kurikulum 2013, 3) Meningkatnya keterampilan guru-guru dalam merancang RPP kurikulum 2013, 4) Tersedianya berbagai alat peraga edukatif tematik sekolah dasar, 5) Meningkatnya keterampilan guru-guru dalam pembuatan alat peraga edukatif tematik.
\end{abstract}

Kata kunci: Sekolah Dasar, Guru, Alat Peraga, Pendampingan

\section{ABSTRACT}

Partners in PKM activities is Teladan Private Elementary Schools of North Sumatra. Problems experienced by partners are: 1) The lack of teachers' knowledge about innovative learning so that learning takes place in a conventional and monotonous manner, 2) Some teachers have not received 2013 curriculum training so that it is difficult to implement it, 3) Some teachers are unable to design Learning Implementation Plans (RPP) well, 4) The unavailability of learning aids, 5) The lack of skills of teachers in making thematic educative teaching aids. The method of approach in implementing PKM uses education, training, practice and mentoring methods. The resulting outputs include: 1) Increased teacher knowledge about innovative learning in elementary schools, 2) Increased teacher knowledge in implementing the 2013 curriculum, 3) Increased teacher skills in designing the 2013 curriculum RPP, 4) The availability of various educational teaching aids elementary school thematic, 5) Increased skills of teachers in making thematic educational teaching aids.

Keywords: Elementary Schools, Teacher, Teaching Aids, Assistance

\section{PENDAHULUAN}

Pendidikan merupakan pondasi utama

bagi seseorang dalam menuntut ilmu untuk meraih keberhasilan dan kesuksesan di masa depan. Pendidikan yang paling utama berada di tingkat Sekolah Dasar (SD), pada tingkat inilah karakter dan mental seseorang akan terbentuk dan sangat berpengaruh pada masa depannya 
kelak. (Taufik, 2014). Dalam pembelajaran di tingkat SD pada masa sekarang ini yang semakin maju, seharusnya prasarana yang ada di SD juga memadai seperti halnya pendidikan di SMP, SMA atau Perguruan Tinggi. Tetapi kenyataan di lapangan menunjukkan SD yang berada di daerah pinggiran kota begitu minim sarana dan prasarana. Demikian juga halnya dengan kualitas mengajar guru SD yang ratarata masih belum memadai (kurang berkualitas) seperti dalam menyajikan materi pelajaran tanpa disertai dengan penggunaan alat peraga atau media pembelajaran.

Mitra kegiatan PKM ini adalah SD Swasta Teladan Sumatera Utara yang berada di jalan pendidikan No 62, Kecamatan Medan Helvetia. Sekolah Dasar ini umumnya menyelenggarakan pendidikan menggunakan kurikulum KTSP, tetapi pada Tahun Akademik 2018/2019 sekolah ini telah mulai menerapkan Kurikulum 2013 pembelajaran tematik terpadu yang penerapannya dimulai pada kelas 1 dan kelas 4. Penerapan pembelajaran tematik terpadu kurikulum 2013 akan berlanjut pada kelas 2 dan kelas 5 serta kelas 3 dan kelas 6 .

Berdasarkan wawancara langsung dengan kepala sekolah Bapak Monang Simarmata, didapatkan informasi pelaksanaan pembelajaran di kelas 1 dan kelas 4 yang dilaksanakan para guru belum mencerminkan pembelajaran tematik yang sebenarnya melainkan masih terlihat seperti pembelajaran KTSP. Lebih lanjut Pak Monang menjelaskan hal ini terjadi disebabkan kurangnya pemahaman guru-guru di sekolah ini dalam mengimplementasikan pembelajaran tematik terpadu sekolah dasar sesuai dengan kurikulum K-13.

SD Swasta Teladan Sumatera Utara memiliki guru sebanyak 13 orang dengan latar belakang pendidikan seluruhnya sarjana pendidikan (S1). Guru yang telah bersertifikasi sebanyak 3 orang dan kebanyakan guru di SD ini masih berusia muda. Guru dengan usia muda seharusnya lebih energik dan penuh kreatifitas dalam melaksanakan pembelajaran yang inovatif sesuai kurikulum yang berlaku. Guru memunyai peran sebagai adapters, lebih dari hanya pelaksana kurikulum, tetapi juga penyelaras kurikulum dengan karakteristik dan kebutuhan siswa. Media pembelajaran merupakan hasil kreativitas guru untuk menyelaraskan kebutuhan siswa dengan tuntutan kurikulum (Sanjaya, 2010). Akan tetapi fakta di lapangan menunjukkan hampir semua guru melaksanakan proses pembelajaran secara monoton tanpa adanya inovasi pelaksanaan pembelajaran (Irfandi dkk, 2018)

Pengamatan terhadap pelaksanaan pembelajaran yang dilakukan tim ketika proses pembelajaran berlangsung di beberapa kelas, menunjukkan pembelajaran yang diterapkan guru dengan metode konvensional dan kurang bervariasi. Para guru mengajar secara apa adanya dengan menuliskan materi di papan tulis tanpa disertai alat bantu pembelajaran seperti alat peraga atau media pembelajaran yang dapat membantu siswa menerima informasi pembelajaran (Arsyad, 2015). Akibatnya siswa di kelas secara umum terlihat pasif, aktivitas siswa lebih banyak mencatat dan mendengarkan guru. Penerapan pembelajaran dengan metode konvensional ini berdampak pada minimnya daya serap siswa terhadap materi pelajaran. Berdasarkan pengamatan tim pada Daftar Kumpulan Nilai Siswa di SD ini, terlihat sebagian siswa yang nilainya rendah dan tidak tuntas.

Dari wawancara yang dilakukan kepada para guru diperoleh informasi bahwa mereka mengalami kesulitan dalam menyiapkan (mendesain) pembelajaran tematik SD berdasarkan kurikulum 2013. Banyak yang tidak dipahami guru terkait dengan penerapan kurikulum 2013 seperti penyusunan RPP tematik yang baik, pemilihan media yang multifungsi dan sesuai kompetensi dasar, penilaian, remedial, dan pelaksanaan pembelajaran yang masih jelas kelihatan pergantiannya dari mata pelajaran satu ke mata pelajaran lainnya. RPP yang digunakan guru sebagian berasal dari internet yang langsung dipakai dan minim modifikasi karena pengetahuan yang rendah tentang penyusunan RPP Kurikulum 2013 yang baik. Guru-guru berharap bisa mendapatkan pendampingan dalam penyusunan RPP dan penerapannya di kelas.

Pembelajaran tematik adalah pembelajaran yang menggunakan tema dalam mengaitkan beberapa mata pelajaran sehingga dapat memberikan pengalaman bermakna kepada siswa (Effendi, 2009). Trianto (2010) menyatakan bahwa pembelajaran tematik dimaknai sebagai pembelajaran yang dirancang berdasarkan tema-tema tertentu, dalam pembahasannya tema itu ditinjau dari berbagai mata pelajaran.

Pembelajaran tematik memberi penekanan pada pemilihan suatu tema yang spesifik yang sesuai dengan materi pelajaran, 
untuk mengajar satu atau beberapa konsep yang memadukan berbagai informasi. Persoalannya, dalam praktik sejumlah guru masih mengalami kesulitan mengordinasikan beberapa mata pelajaran tersebut dalam satu tema. Akibatnya, guru seolah-olah mengajarkan semacam kumpulan mata pelajaran namun disajikan secara bergantian. (Krissandi \& Rusmawan, 2015).

Agar dapat menerapkan kurikulum 2013 dalam pembelajaran tematik seharusnya semua guru sudah mendapatkan pelatihan kurikulum 2013, akan tetapi pada kenyataannya di sekolah mitra ini belum seluruhnya guru mendapatkan pelatihan kurikulum 2013 sehingga guru-guru mengalami berbagai kendala dalam penerapan kurikulum 2013 mulai dari mempersiapkan perangkat pembelajaran, implementasi pembelajaran tematik, dan penilaian.

Solusi yang ditawarkan untuk menyelesaikan permasalahan mitra antara lain

1) Pelatihan pembelajaran inovatif di sekolah dasar

2) Pelatihan Kurikulum 2013 sekolah dasar,

3) Workshop penyusunan RPP pembelajaran tematik,

4) Pendampingan pembuatan berbagai alat peraga pembelajaran,

5) Workshop pembuatan alat peraga pembelajaran tematik.

\section{METODE KEGIATAN}

Metode pelaksanaan kegiatan PKM untuk menyelesaikan permasalahanpermasalahan mitra menggunakan metode pendekatan dalam bentuk pelatihan, workshop dan pendampingan. Permasalahanpermasalahan yang akan diselesaikan antara lain : 1) Minimnya pengetahuan guru-guru tentang pembelajaran yang inovatif sehingga pembelajaran berlangsung secara konvensional dan monoton, 2) Kendala dalam penerapan Kurikulum 2013 dikarenakan guru belum mendapatkan pelatihan Kurikulum 2013, 3) Sebagian guru tidak mampu merancang Rencana Pelaksanaan Pembelajaran (RPP) dengan baik, 4) Tidak tersedianya alat peraga pembelajaran, 5) Minimnya keterampilan guru-guru dalam pembuatan alat peraga edukatif tematik. Metode pendekatan yang ditawarkan untuk menyelesaikan permasalahan prioritas tersebut dilakukan dengan tahapantahapan sebagai berikut :

\section{Tahap Persiapan}

- Melakukan koordinasi dengan LPPM UNIMED untuk izin pelaksanaan kegiatan

- Menyampaikan surat izin pelaksanaan kegiatan kepada pihak sekolah

- Melakukan penyusunan jadwal kegiatan dan juga persiapan bahan-bahan serta alat yang dibutuhkan

- Melaksanakan FGD dengan kepala sekolah untuk mendiskusikan bentuk kegiatan, jumlah peserta dan tempat kegiatan

- Mensosialisasikan program dan kegiatan yang akan dilaksanakan kepada seluruh guru

\section{Tahap Pelaksanaan}

- Melaksanakan pelatihan pembelajaran inovatif di aula SD Swasta Telada Sumatera Utara

- Melaksanakan pelatihan Kurikulum 2013 sekolah dasar

- Melaksanakan workshop penyusunan RPP pembelajaran tematik terpadu

- Melakukan pendampingan pembuatan berbagai model alat peraga pembelajaran tematik untuk diserahkan kepada mitra

- Melaksanakan workshop pembuatan alat peraga pembelajaran tematik.

- Melaksanakan pendampingan simulasi implementasi pembelajaran tematik terpadu SD kurikulum 2013

\section{Tahap Evaluasi}

Untuk mengetahui keberhasilan pelaksanaan kegiatan PKM maka dilakukan evaluasi pelaksanaan program. Beberapa hal yang dijadikan evaluasi pelaksanaan program, yaitu:

a. Kualitas RPP pembelajaran tematik terpadu yang disusun guru

b. Kualitas alat peraga pembelajaran tematik terpadu.

c. Tanggapan kepala sekolah dan guru-guru terhadap pelaksanaan kegiatan PKM.

\section{HASIL \& PEMBAHASAN}

Kegiatan pengabdian kepada masyarakat yang berjudul "PKM Guru-Guru SD Mendesain Pembelajaran Inovatif Berbasis Alat Peraga Edukatif Tematik Di Kecamatan Medan Helvetia" telah dilaksanakan dari Bulan Juni sampai dengan Bulan Agustus 2019. Kegiatan dilakukan melalui beberapa tahapan yaitu tahap persiapan, tahap pelaksanaan, dan tahap evaluasi. Adapun setiap tahapan kegiatan sebagai berikut. 


\section{Persiapan}

Tim pelaksana kegiatan membangun kemitraan dengan berkoordinasi ke Lembaga Penelitian dan Pengabdian Masyarakat Universitas Negeri Medan (LPPMP UNIMED) terkait penyediaan administrasi pelaksanaan kegiatan seperti surat izin pelaksanaan kegiatan, surat tugas tim pelaksana, daftar hadir peserta kegiatan, berita acara pelaksanaan kegiatan, berita acara serah terima alat dan pendamping saat pelaksanaan kegiatan. Selanjutnya tim pelaksana menyampaikan surat izin pelaksanaan kegiatan yang sudah diperoleh dari LPPMP UNIMED kepada pihak sekolah mitra yaitu SD Swasta Teladan Sumatera Utara sekaligus menentukan jadwal pelaksanaan sosialisasi kepada guru dan pelaksanaan FGD kegiatan pengabdian yang akan dilakukan. Kegaiatn sosialisasi dan FGD Bersama para guru memperoleh hasil antara lain :

a. Peserta Kegiatan adalah seluruh guru SD Swasta Teladan Sumatera Utara dan perwakilan guru (2-5 Orang) tiap sekolah yang tergabung dalam Kelompok Kerja Guru (KKG) wilayah 7 Kecamatan Medan Helvetia yang terdiri dari 7 Sekolah dengan jumlah peserta guru 37 orang.

b. Mitra SD Swasta Teladan Sumatera Utara menyediakan tempat pelaksanaan kegiatan.

c. Pelaksanaan kegiatan dilakukan dalam bentuk pelatihan, workshop dan pendampingan dengan fasilitas pelatihan dan workshop (seminar kit, konsumsi, peralatan dan bahan) disiapkan oleh tim pelaksana.

\section{Pelaksanaan}

Pelaksanaan kegiatan pengabdian kepada masyarakat ini di awali dengan penyajian materi pelatihan tentang pembelajaran-pembelajaran inovatif yang dapat di tingkat sekolah dasar yang disampaikan oleh ketua pelaksana Muhammad Aswin Rangkuti. Sebelum kegiatan pelatihan dimulai, peserta diberikan perlengkapan seminar kit yang berisikan bahan sajian pelatihan dan alat tulis. Peserta terlihat antusias mendengarkan materi yang disampaikan dan aktif bertanya untuk hal yang belum dipahami. Kemudian kegiatan dilanjutkan dengan pelatihan kurikulum 2013 tematik terpadu yang disampaikan oleh anggota tim pelaksana Imelda Free Unita Manurung. Pada saat pelaksanaan pelatihan tentang kurikulum 2013 hampir semua peserta yang bertanya. Ini menunjukkan antusias dan keingintahuan yang tinggi dari peserta dalam penerapan pembelajaran tematik terpadu Kurikulum 2013. Peserta yang bertanya pada umumnya adalah guru-guru yang belum pernah mengikuti pelatihan tentang kurikulum 2013. Berdasarkan diskusi tanya jawab ditemukan adanya guru yang selama ini menerapkan remedial secara keliru karena siswa yang mengikuti remedial akhirnya mendapatkan nilai yang sama dengan siswa yang tidak mengikuti remedial. Dari diskusi pada pelatihan ini juga para guru mendapatkan pengetahuan tentang contoh gambaran rancangan media atau alat peraga yang dapat disiapkan oleh guru sesuai tema dan kompetensi dasarnya dengan biaya yang minim.

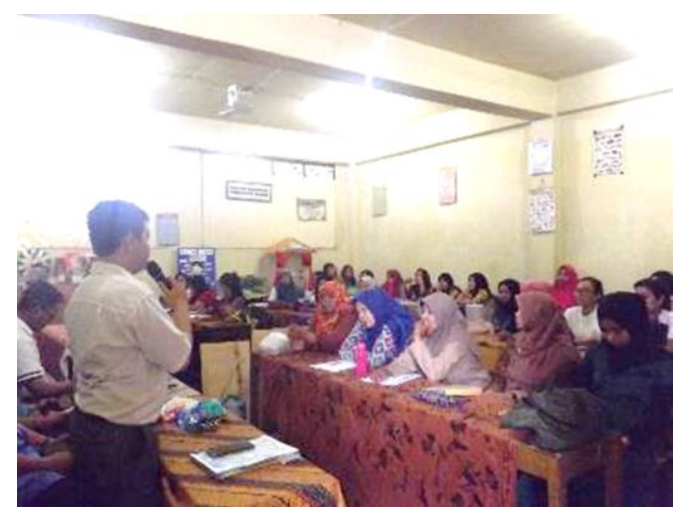

Gambar 1. Sosialisasi Program Dan FGD

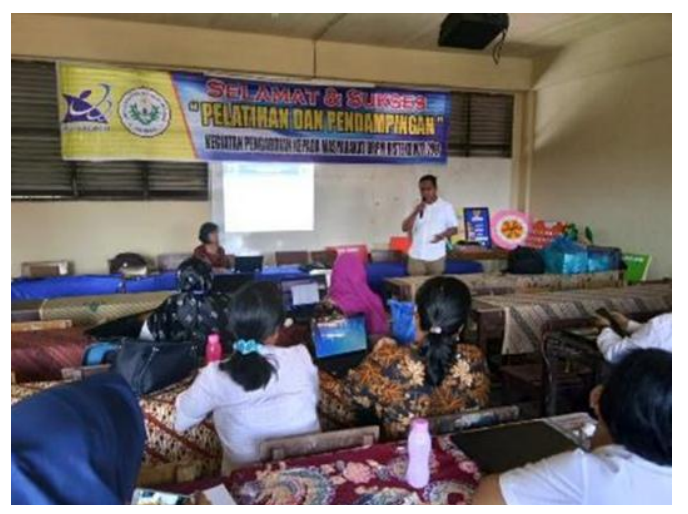

Gambar 2. Pelatihan Pembelajaran Inovatif

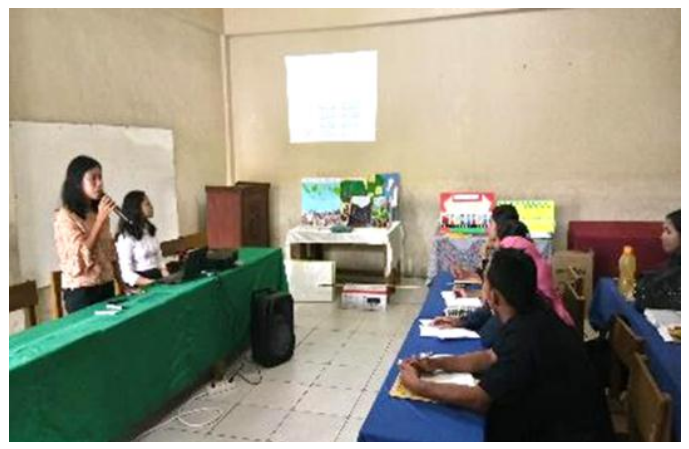

Gambar 3. Pelatihan Kurikulum 2013 


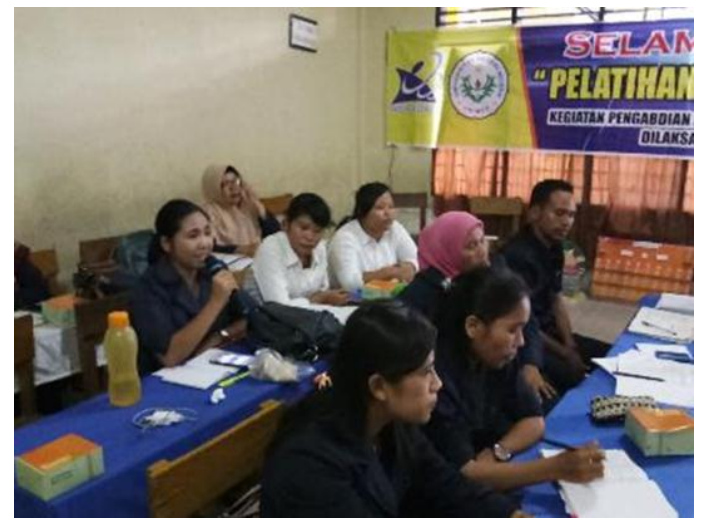

Gambar 4. Peserta Aktif Bertanya

Kegiatan selanjutnya adalah workshop penyusunan rencana pelaksanaan pembelajaran (RPP) berdasarkan Kurikulum 2013. Sebelumnya tim pelaksana sudah menginformasikan kepada seluruh peserta agar membawa file RPP (softkopy/hardkopy) sesuai kelasnya masing-masing dan laptop. Workshop dimulai dengan penyajian materi tentang sistematika RPP dan contoh RPP untuk salah satu tema di kelas rendah dan kelas tinggi. Setelah materi disajikan tim melakukan bedah RPP beberapa guru yang selama ini mereka gunakan. RPP yang selama ini digunakan guru kurang baik karena pada umumnya didapatkan dari blog yang ada di internet. Kasus yang terlihat pada RPP yang digunakan guru diantaranya pemilihan bahan ajar yang tidak sesuai, aktivitas pembelajaran masih minim menunjukkan implementasi kurikulum 2013 dengan pendekatan saintifik (mengamati, menanya, mencoba, menalar dan mengkomunikasikan), tes yang tertera pada RPP tidak sesuai dengan indikator pembelajaran ranah kognitif, dan pemilihan media yang kurang tepat. Untuk memperbaiki kesalahan ini tim memberikan koreksi yang seharusnya. Kemudia peserta dibagi menjadi 6 kelompok yang terdiri dari 3 kelompok kelas rendah dan 3 kelompok kelas tinggi. Masingmasing kelompok diberikan tugas bekerja dalam kelompok untuk menyusun RPP berdasarkan salah satu tema. Di akhir kegiatan masing-masing kelompok guru menampilkan RPP mereka dan divalidasi langsung oleh kelompok lainnya Bersama tim pelaksana. Berdasarkan workshop ini telah dihasilkan peningkatan kualitas RPP yang disusun guru lebih baik dari sebelumnya.

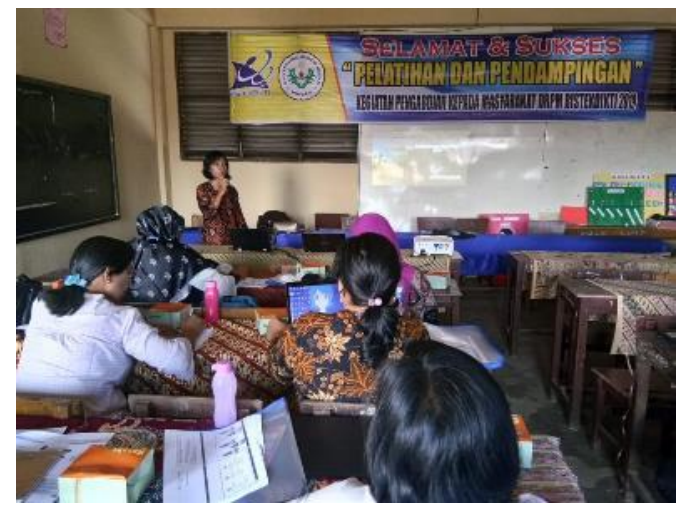

Gambar 5. Workshop Penyusunan RPP K-13

Pelaksanaan kegiatan selanjutnya yaitu tim pelaksana merancang dan membuat beberapa model alat peraga pembelajaran tematik dengan jumlah 14 alat peraga. Perancangan jenis alat peraga dilakukan oleh tim pelaksana, sementara untuk pembuatannya dilakukan oleh beberapa mahasiswa yang dilibatkan dalam program pengabdian ini dengan bimbingan tim pelaksana. Dengan melibatkan mahasiswa dalam pembuatan alat peraga ini diharapkan akan berdampak positip bagi mahasiswa sebagai calon guru dalam mempersiapkan alat peraga atau media pembelajaran. Proses pembuatan model-model alat peraga ini berlangsung selama 3 minggu di Laboratorium Media Jurusan Fisika Universitas Negeri Medan.

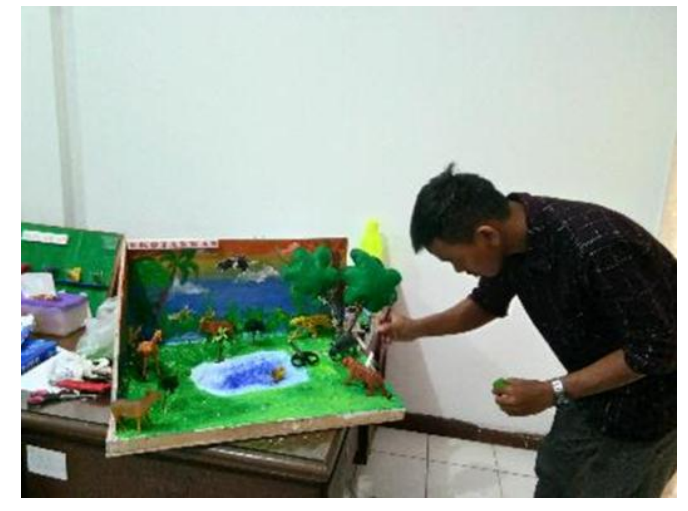

Gambar 6. Pembuatan Model-Model Alat Peraga

Kegiatan selanjutnya adalah workshop pembuatan alat peraga oleh para guru peserta kegiatan secara berkelompok. Alat dan Bahan yang diperlukan pada workshop dibawa langsung oleh tim pelaksana yang sudah disediakan sebelumnya. Pelaksananaan kegiatan workshop ini dibantu oleh beberapa mahasiswa agar dapat mendampingi guru ketika membuat alat peraga. Pada saat workshop terlihat peserta sangat semangat dan antusias menyelesaikan alat peraga yang 
menjadi tugas mereka dalam kelompoknya. Hasil yang diperoleh dari kegiatan ini sejalan dengan hasil yang diperoleh Taneo, dkk (2018) yaitu meningkatnya kreatifitas guru dalam mempersiapkan alat peraga yang sesuai dengan materi pembelajaran.

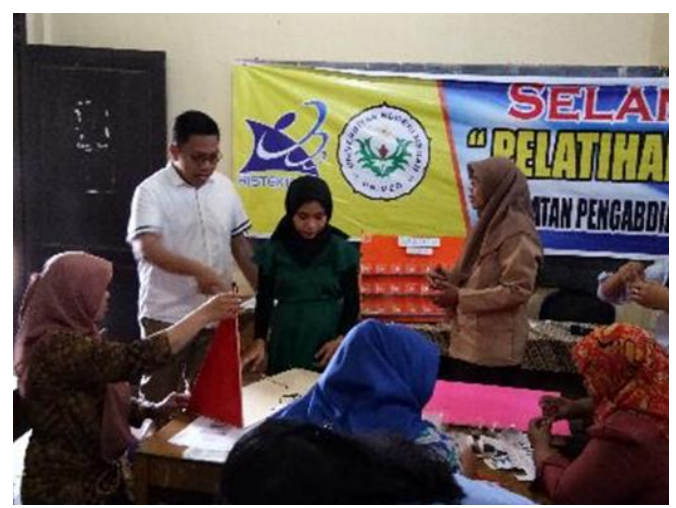

Gambar 7. Pembuatan Alat Peraga Oleh GuruGuru Peserta Kegiatan

Alat peraga yang dihasilkan dari pelaksanaan workshop ini sebanyak 6 alat peraga yang terdiri dari 3 alat peraga kelas rendah dan 3 alat peraga kelas tinggi. Alat peraga yang dihasilkan divalidasi langsung oleh masing-masing kelompok peserta bersama tim pelaksana. Hasilnya menunjukkan para guru telah mampu membuat alat peraga sendiri dengan kualitas yang baik.

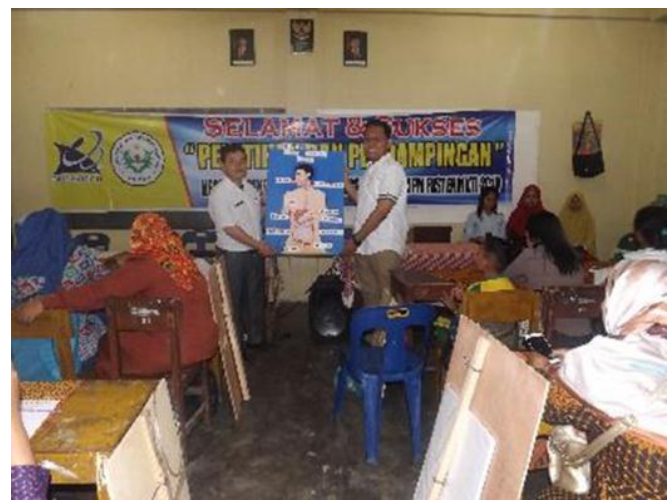

Gambar 8. Guru-Guru Bersemangat Membuat alat Peraga Pembelajaran Tematik

Pelaksanaan kegiatan yang terakhir adalah pendampingan simulasi implementasi pembelajaran tematik menggunakan alat peraga yang telah dihasilkan melalui kegiatan sebelumnya. Perwakilan masing-masing kelompok guru berperan sebagai guru model dan peserta lainnya sebagai siswa. Dari kegiatan ini dihasilkan gambaran pelaksanaan pembelajaran tematik yang sudah baik. Perpindahan antar materi pelajaran yang dilakukan guru sudah tidak kaku. Trianto
(2010) menyatakan bahwa pembelajaran tematik dimaknai sebagai pembelajaran yang dirancang berdasarkan tema-tema tertentu, dalam pembahasannya tema itu ditinjau dari berbagai mata pelajaran. Penerapan pembelajaran tematik sudah menggunakan alat peraga yang sesuai dengan tema. Adanya alat peraga ini membuat siswa (peserta guru) dalam proses pembelajaran aktif bersaintifik. Penggunaan alat peraga akan memudahkan siswa memahami konsep materi yang disampaikan, oleh karena itu guru harus kreatif dalam menyiapkan pembelajaran (Taneo dkk, 2018) Siswa diberikan kesempatan mengamati alat peraga kemudian diminta untuk memberikan pertanyaan dari yang mereka amati. Siswa juga diberikan kesempatan untuk mencoba menggunakan alat peraga. Kemudian siswa diberikan lembar kerja untuk diselesaikan dan diakhir pembelajaran mereka diminta untuk memaparkan hasil penyelesaian lembar kerja tersebut. Diakhir pelaksanaan kegiatan dilanjutkan dengan penyerahan berbagai model alat peraga pembelajaran tematik beserta alat peraga buatan guru pada kegiatan workshop kepada mitra. Berbagai alat peraga yang diberikan kepada mitra yaitu : 1). Sistem Peredaran Darah Pada Manusia, 2) Sistem Pernafasan, 3) Sistem Pencernaan Makanan, 4) Pancasila, 5). Ekojarkan (Ekosistem dan Jaring-Jaring Makanan), 6) Dakota (FPB dan KPK), 7) Wayang Baperan (Bermain Peran). 8) Poka (Pohon Angka), 9) Kosa Kata, 10) Nilai Tempat, 11) Jam Sudut, 12) Perubahan Energi, 13) Dataran TinggiRendah, 14) Scrap Book Keanekaragaman Budaya dan Suasana

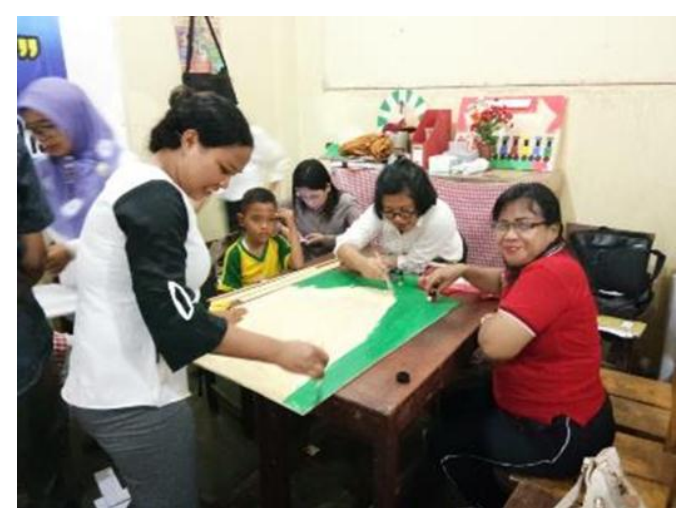

Gambar 9. Peyerahan Alat Peraga Kepada Mitra 


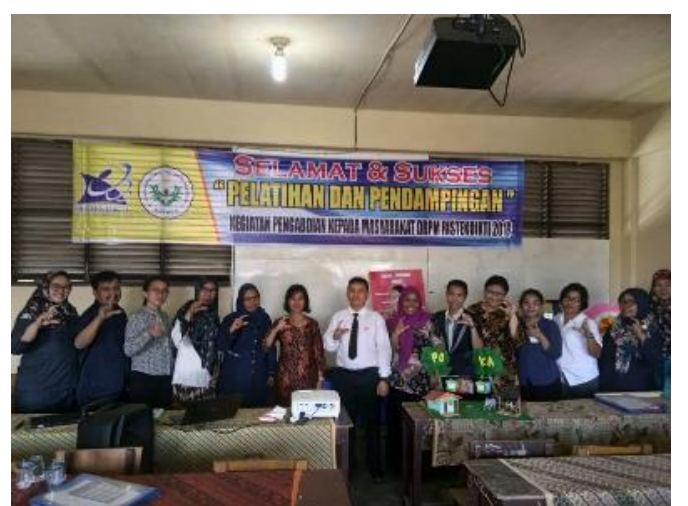

Gambar 10. Foto Bersama Dengan Guru-Guru

\section{Evaluasi}

Evaluasi kegiatan dilakukan dengan pengamatan langsung terhadap RPP kelompok yang dihasilkan, alat peraga setiap kelompok, dan respon peserta melalui pemberian angket kepada guru-guru peserta kegiatan. Hasil evaluasi terhadap RPP masing-masing kelompok pada aspek indikator pembelajaran, tujuan pembelajaran, materi, pemilihan media, tes ditunjukkan pada Tabel 1 .

Tabel 1. Penilaian RPP Kelompok

\begin{tabular}{lrrcccc}
\hline Kel & I & II & III & IV & V & VI \\
\hline Nilai & 85 & 90 & 85 & 80 & 75 & 85 \\
\hline Rt & \multicolumn{8}{c}{83,33} \\
\hline
\end{tabular}

Berdasarkan penilaian terhadap RPP yang disusun oleh peserta dalam kelompoknya telah menunjukan hasil yang baik dengan nilai rata-rata 83,33. Hal ini menunjukkan adanya peningkatan pengetahuan dan keterampilan para guru peserta kegiatan dalam penyusunan RPP tematik terpadu sesuai Kurikulum 2013.

Hasil evaluasi yang dilakukan tim pelaksana terhadap alat-alat peraga pembelajaran tematik buatan guru dalam kelompoknya yang dinilai berdasarkan penampilan, kerapian, pewarnaan, ketahanan, kerumitan seperti pada Tabel 2

Tabel 2. Penilaian Alat Peraga Buatan Peserta

\begin{tabular}{lrccccc}
\hline Kel & I & II & III & IV & V & VI \\
\hline Nilai & 90 & 80 & 85 & 85 & 95 & 85 \\
\hline Rt & \multicolumn{7}{c}{86,67} \\
\hline
\end{tabular}

Penilaian terhadap alat peraga pembelajaran tematik yang dibuat oleh peserta dalam kelompoknya telah menunjukan hasil yang baik dengan nilai rata-rata 86,67. Hal ini menunjukkan adanya peningkatan pengetahuan dan keterampilan para guru peserta kegiatan dalam pembuatan alat peraga pembelajaran tematik.
Berdasarkan respon peserta terhadap pelaksanaan kegiatan melalui angket yang dibagikan meliputi kebermanfaatan kegiatan yang dilaksanakan untuk peningkatan pengetahuan dan keterampilan, kesesuaian kegiatan dengan permasalahan yang dialami, dan kepuasan terhadap sikap tim pelaksana dalam menjalankan seluruh tahapan kegiatan seperti pada Gambar 11

\section{Respon Peserta}

\section{Keseluruhan}

Kepuasan

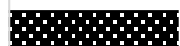

Kesesuaian

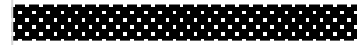

Kebermanfaatan

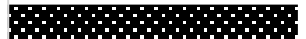

$\begin{array}{llllll}84.00 & 86.00 & 88.00 & 90.00 & 92.00 & 94.00\end{array}$

\section{Gambar 11. Respon Peserta Terhadap Pelaksanaan Kegiatan}

Gambar 11 menunjukkan secara keseluruhan respon peserta terhadap pelaksanaan kegiatan sangat baik dengan skor sebesar 90, sementara untuk skor kepuasan, kesesuaian, dan kebermanfaatn berturut-turut sebesar 88, 90,50 dan 92. Hal ini menunujukkan bahwa kegiatan yang dilaksanakan memberikan dampak yang positif kepada mitra sasaran kegiatan.

\section{KESIMPULAN \& SARAN}

Berdasarkan hasil pelaksanaan kegiatan pengabdian ini dapat disimpulkan :

1. Pengetahuan guru tentang pembelajaran inovatif di sekolah dasar telah mengalami peningkatan,

2. Pengetahuan guru-guru dalam menerapkan kurikulum 2013 telah meningkat lebih baik dibandingkan sebelum pelaksanaan kegiatan,

3. Guru-guru telah mampu merancang RPP kurikulum 2013 dengan baik,

4. Berbagai alat peraga edukatif tematik sekolah dasar telah tersedia untuk digunakan dalam pembelajaran,

5. Guru-guru telah memiliki keterampilan yang baik dalam pembuatan alat peraga edukatif tematik.

Berdasarkan hasil pengabdian disarankan agar para guru dapat 
mempersiapkan RPP sendiri tanpa menggunakan RPP yang beredar di Internet yang kualitasnya belum tentu baik, disamping itu para guru SD juga diharapkan mampu memanfaatkan bahan-bahan yang ada disekitarnya menjadi alat peraga edukatif yang dapat dijadikan sebagai alat bantu dalam penyampaian informasi pembelajaran kepada siswa dan membuat siswa akan lebih aktif dalam pembelajaran.

\section{UCAPAN TERIMA KASIH}

Kami mengucapkan terimakasih kepada semua pihak yang terlibat dalam pelaksanaan kegiatan pengabdian masyarakat ini, khususnya kepada Direktorat Riset dan Pengabdian Masyarakat Kementrian Riset Teknologi dan Pendidikan Tinggi (DRPM Ristekdikti) yang telah memberikan pendanaan untuk pelaksanaan kegiatan pengabdian masyarakat ini.

\section{DAFTAR PUSTAKA}

Arsyad, A. 2015. Media Pembelajaran. Jakarta: PT. Raja Grafindo Persada

Efendi, M. (2009). Kurikulum dan Pembelajaran: Pengantar Ke Arah Pemahaman KBK, KTSP dan SBI. Malang: FIP Universitas Negeri Malang.

Irfandi, I., Faisal, F., Hasibuan, N. I., \& Panggabean, D. D. (2018). The Dissemination Of Technology-Based Learning Media For Elementary School Teachers In The District Of Sijunjung. Journal of Community Research and Service, 2(1), 198-205

Krissandi, A. D. S., \& Rusmawan, R. (2015). Kendala guru sekolah dasar dalam implementasi Kurikulum 2013. Cakrawala pendidikan, (3).

Sanjaya, W. (2010). Kurikulum dan Pembelajaran. Jakarta: Kencana.

Taneo, P. N., Daniel, F., \& Bien, Y. I. (2018). Pendampingan Pembuatan dan Penerapan Alat Peraga Matematika bagi Guru SD Gugus II Kecamatan Amanuban Barat. Publikasi Pendidikan, 8(3), 229-233.

Taufiq, A. (2014). Pendidikan Anak di SD. (online) Tersedia di http://repository.ut.ac.id/4122/1/PDGK44 03-M1.pdf. Diakses tanggal 10 September 2019

Trianto. (2010). Mengembangkan Model Pembelajaran Tematik. Jakarta: Prestasi Pustaka. 